\title{
Effect of Plant Growth Regulators on Micro-Propagation of Selected Sri Lankan Traditional and Improved Rice Cultivars (Oryza sativa L.)
}

\section{M. P. Dissanayaka and Nilanthi Dahanayake}

Department of Agricultural Biology, Faculty of Agriculture, University of Ruhuna, Mapalana, Kamburupitiya, Sri Lanka.daha_27@yahoo.com

\begin{abstract}
In this study five selected Sri Lankan traditional rice varieties (Kaluheenati, Sulaai, Suwadhal, Dostara Heenati) (Oryza sativa L.) and five improved rice varieties (At362, Bg94/1, Bg358, Bg357, Bg379) were examined for callus induction, plant regeneration and rooting using in vitro techniques. Seeds were cultured in five different hormone concentrations; 1.0, 1.5, 2.0, 2.5, $3.0 \mathrm{mg} / 1$ 2, 4- Dichlorophenoxy acitic acid (2, 4-D) and $0.1 \mathrm{mg} / 16$ - Benzyl adenine purine (BAP) on Murashige and Skoogs (MS) basal medium for callus induction. Proliferated calli were transferred to five different hormone concentrations; 1.0, 1.5, 2.0, 2.5, $3.0 \mathrm{mg} / \mathrm{l} \mathrm{BAP}$ with $0.1 \mathrm{mg} / \mathrm{l}$ Indole acetic acid (IAA) to regenerate shoots. Regenerated shoots were transferred to three different hormone concentrations; 1.5, 2.0, $3.0 \mathrm{mg} / 1$ Indole butric acid (IBA) for rooting. Complete Randomized Design (CRD) was used with ten replicates and data was analyzed by SAS 9.1.3 version.

The interaction between plant varieties and different hormone concentrations are highly significant for callus diameter, number of shoots per explants and root length. All tested rice cultivars (100\%) were able to produce callus however only $40 \%$ of rice varieties were regenerate shoots. The regeneration ability of rice varieties varied from $0 \%$ to $100 \%$. All shoots were able to produce $100 \%$ roots in tested IBA concentrations. Among all selected rice varieties $2.0 \mathrm{mg} / 1$ 2, 4-D $+0.1 \mathrm{mg} / \mathrm{l} \mathrm{BAP}$ is most successful for callus induction while $2.0 \mathrm{mg} / \mathrm{l} \mathrm{BAP}+0.1 \mathrm{mg} / 1 \mathrm{IAA}$ and $2.0 \mathrm{mg} / 1 \mathrm{IBA}$ most effective for shoot regeneration and root induction respectively.
\end{abstract}

Key words: Oryza sativa L., callus, regeneration, root induction, hormone

\section{Introduction}

Rice (Oryza sativa L. gramineae/Poaceae) is a monocotyledonous cereal crop which is the world's most important food crop after wheat and maize. Rice is the primary food source for more than a one third of the world's population. More than 90\% of the world's rice is grown and consumed in Asia where $60 \%$ of the earth's people live. Today rice production has been increasing worldwide by large scale adoption of modern high yielding rice varieties and through various improved cultural practices. Even though the rice production 
meets out the current demand, there is an urgent need to double the production in mid 21st century because the current global population of 6.4 billion is expected to reach 7.7 billion by 2020 and 9.5 billion by 2050 (http://www. worldometers.info/world-population/).

If production is less it leads to hunger and famine, especially in the developing countries. Therefore different agronomic practices, traditional plant breeding methods and tissue cultural techniques are commonly use to acquire higher quality yield, and for crop improvement. Considerable research work has been directed towards the rice improvement of varieties and in the study of varieties in relation to their environment.

Plant tissue culture is commonly used to describe the in vitro and aseptic cultivation of any plant part whether a single cell, a tissue, or an organ, on a nutrient medium (Hidayat et al, 2007). Among the in vitro techniques, anther culture, protoplast fusion, leaf culture, root culture and dehusked grain culture are important in rice tissue culture to exploit somaclonal variation for the creation of novel rice varieties (Ram and Singh, 1998).

This study was under taken to establish high shoot regeneration system which can be applied to breed new varieties as well as can be used for gene transformation; to establish high efficient culture method for micropropagation of elite genotypes.

\section{Methodology}

Seeds of ten selected rice varieties (At 362, Bg 94/1, Bg 358, Bg 357, Bg 379/2, Kaluheenati, Sulaai, Suwdhal, Dostaraheenati and Suduheenati) were collected from Plant Genetic Resource Center Ganoruwa, Peradeniya.

Healthy, undamaged mature seeds were selected manually and surface sterilization was done by dipping seeds in 70\% Ethyl alcohol, two minutes. After that seeds were sterilized by $10 \%$ chlorex solution for 30 minutes. Then seeds were washed thoroughly more than 4 times using autoclaved distilled water.

Murashige and skoogs medium (MS basal medium) composed with different hormone concentrations was used for callus induction (Table 1a), shoot regeneration (Table $1 \mathrm{~b}$ ) and root induction (Table 1c).

\begin{tabular}{|c|c|c|}
\hline Treatments & 2, 4-D Concentration & BAP Concentration \\
\hline $\mathrm{T} 1$ & $1.0 \mathrm{mg} / \mathrm{l}$ & $0.1 \mathrm{mg} / 1$ \\
\hline $\mathrm{T} 2$ & $1.5 \mathrm{mg} / \mathrm{l}$ & $0.1 \mathrm{mg} / 1$ \\
\hline $\mathrm{T} 3$ & $2.0 \mathrm{mg} / \mathrm{l}$ & $0.1 \mathrm{mg} / 1$ \\
\hline $\mathrm{T} 4$ & $2.5 \mathrm{mg} / \mathrm{l}$ & $0.1 \mathrm{mg} / 1$ \\
\hline $\mathrm{T} 5$ & $3.0 \mathrm{mg} / \mathrm{l}$ & $0.1 \mathrm{mg} / \mathrm{l}$ \\
\hline
\end{tabular}

Table 1a: Hormone concentrations for callus induction 


\begin{tabular}{|c|c|c|}
\hline Treatments & BAP Concentration & IAA Concentration \\
\hline $\mathrm{T} 1$ & $1.0 \mathrm{mg} / 1$ & $0.1 \mathrm{mg} / \mathrm{l}$ \\
\hline $\mathrm{T} 2$ & $1.5 \mathrm{mg} / 1$ & $0.1 \mathrm{mg} / \mathrm{l}$ \\
\hline $\mathrm{T} 3$ & $2.0 \mathrm{mg} / 1$ & $0.1 \mathrm{mg} / \mathrm{l}$ \\
\hline $\mathrm{T} 4$ & $2.5 \mathrm{mg} / 1$ & $0.1 \mathrm{mg} / \mathrm{l}$ \\
\hline $\mathrm{T} 5$ & $3.0 \mathrm{mg} / \mathrm{l}$ & $0.1 \mathrm{mg} / \mathrm{l}$ \\
\hline
\end{tabular}

Table 1b: Hormone concentrations on shoot regeneration

\begin{tabular}{|c|c|}
\hline Treatments & IBA Concentration \\
\hline T1 & $1.5 \mathrm{mg} / \mathrm{l}$ \\
\hline $\mathrm{T} 2$ & $2.0 \mathrm{mg} / \mathrm{l}$ \\
\hline $\mathrm{T} 3$ & $2.5 \mathrm{mg} / \mathrm{l}$ \\
\hline
\end{tabular}

Table 1c: Hormone concentration on root induction

Thirty days old compact, yellowish colour calli were transferred to shoot regeneration. Thirty days old healthy uniform shoots were transferred to root induction.

\section{Data collection}

Number of days taken for callus induction and calli diameter was measured in callus stage. After thirty days from seed initiation measure calli diameter, proliferated calli were grouped as follows; (Group 1- $<0.5 \mathrm{~cm}$, Group 2- $>0.5$ $-1.0 \mathrm{~cm}$ Group 3- >1.0 - $1.5 \mathrm{~cm}$, Group 4- > $1.5-2.0 \mathrm{~cm}$, Group 5. $>2 \mathrm{~cm}$ ). Number of days taken for shoot induction, number of shoots per explants, number of days taken for root induction were counted and root length was measured. Complete Randomized Design (CRD) with ten replicates was used. Data was analyzed by SAS 9.1.3 version.

\section{Results and Discussion}

\section{Effect of different 2, 4-D concentrations on callus induction}

Number of days taken to callus initiation showed significant difference between different hormone concentrations and the variety. Similar findings were also reported by Pushpam and Sree Rangasamy (2000) and Shanthi et al (2010) for callus induction from mature caryopsis. According to our results, $1.5 \mathrm{mg} / 12,4-\mathrm{D}+0.1 \mathrm{mg} / \mathrm{l} \mathrm{BAP}$ is good to obtain callus within minimum number of days (4 days).

Hundred percent of callus induction was recorded by $90 \%$ of tested cultivars (except Bg 379/2) on MS basal medium supplemented with 2, 4 D at all concentrations. However rice cultivar Bg 379/2 was unable to produce callus on MS basal medium supplemented with $1.0 \mathrm{mg} / 1$ and $1.5 \mathrm{mg} / 12$, 4-D with 
0.1mg/1 BAP. Therefore 2.0, 2.5, $3.0 \mathrm{mg} / 1$ 2, 4- D with $0.1 \mathrm{mg} / 1$ BAP hormone concentrations can be use for callus induction in all selected Sri Lankan rice cultivars. The same results were observed by Dahanayaka et al (2011) the highest callus induction was recorded on MS basal medium with $2.5 \mathrm{mg} / 12$, 4-D and $0.1 \mathrm{mg} / 1$ BAP for selected Sri Lankan traditional rice varieties.

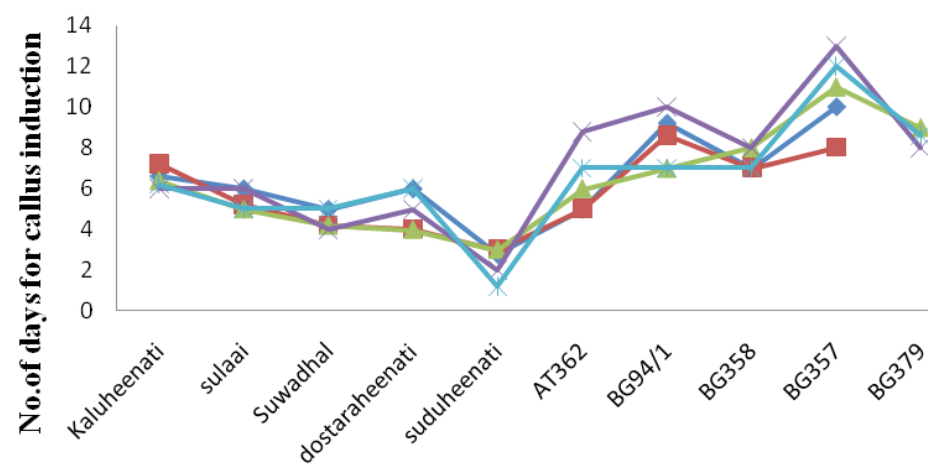

2, 4- D Concentrations (mg/l)

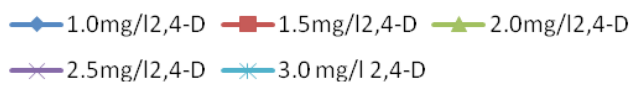

Figure 1: Effect of different 2, 4-D concentrations for callus induction. LSD value for comparison of two treatments means 1.90

\section{Effect of different 2, 4-D concentration for callus diameter}

By the fourth week of callus induction maximum callus diameter $(>1.5 \mathrm{~cm})$ was observed in Sulaai $(1.8 \mathrm{~cm})$ on medium $2.0 \mathrm{mg} / 12$, $4-\mathrm{D}$ with $1.0 \mathrm{mg} / 1 \mathrm{BAP}$ among all tested rice varieties (Plate 1).

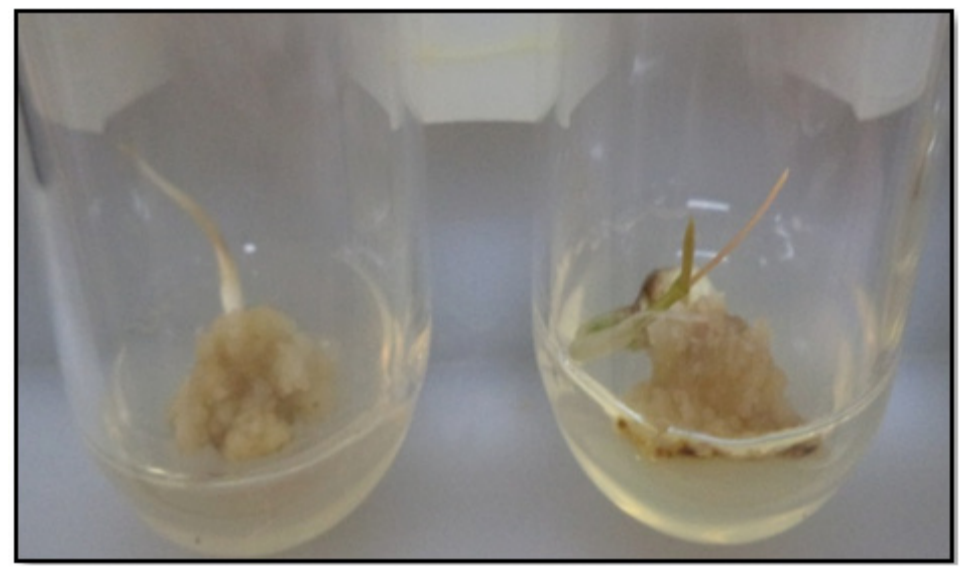

Plate 1: Maximum callus diameter $(1.8 \mathrm{~cm})$ in Sulaai on MS basal medium $2.0 \mathrm{mg} / 1$ 2, 4- D with $0.1 \mathrm{mg} / 1 \mathrm{BAP}$ after 30 days

From all tested cultivars highest callus diameter was observed in MS basal 
medium supplemented with 2.0mg/1 2, 4-D, with $0.1 \mathrm{mg} / 1 \mathrm{BAP}$ (Figure 2). This observations recorded in the present study are as same as findings of Dahanayaka et al (2011). It is recorded that callus diameter is high in traditional rice varieties compare to improved rice varieties at the same age (Figure 2, Plate 2).

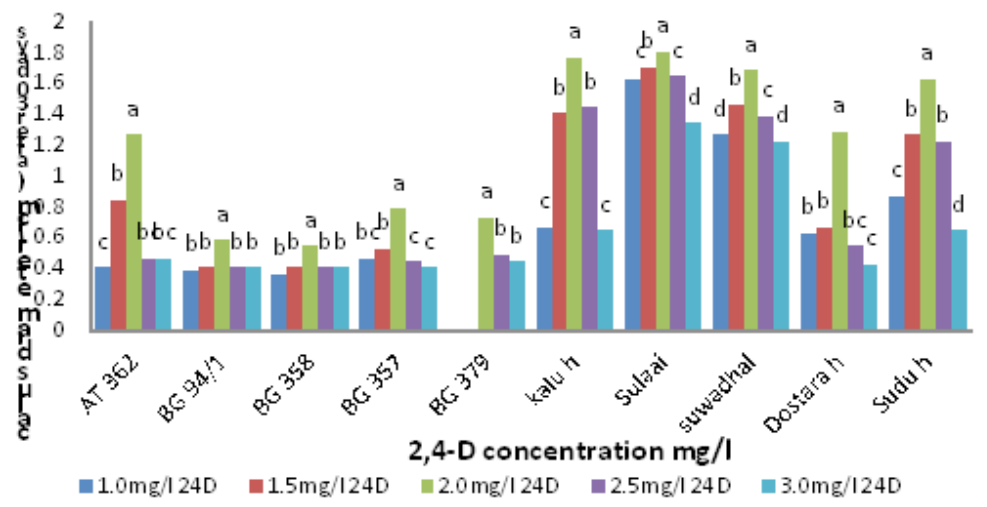

Figure 2: Effect of different 2, 4-D concentration on growth of callus 30 days after seed initiation. The figures with the same latter in each bar in same variety do not differ significantly according to DMRT 0.05 . LSD value for comparison of two treatments means 0.99

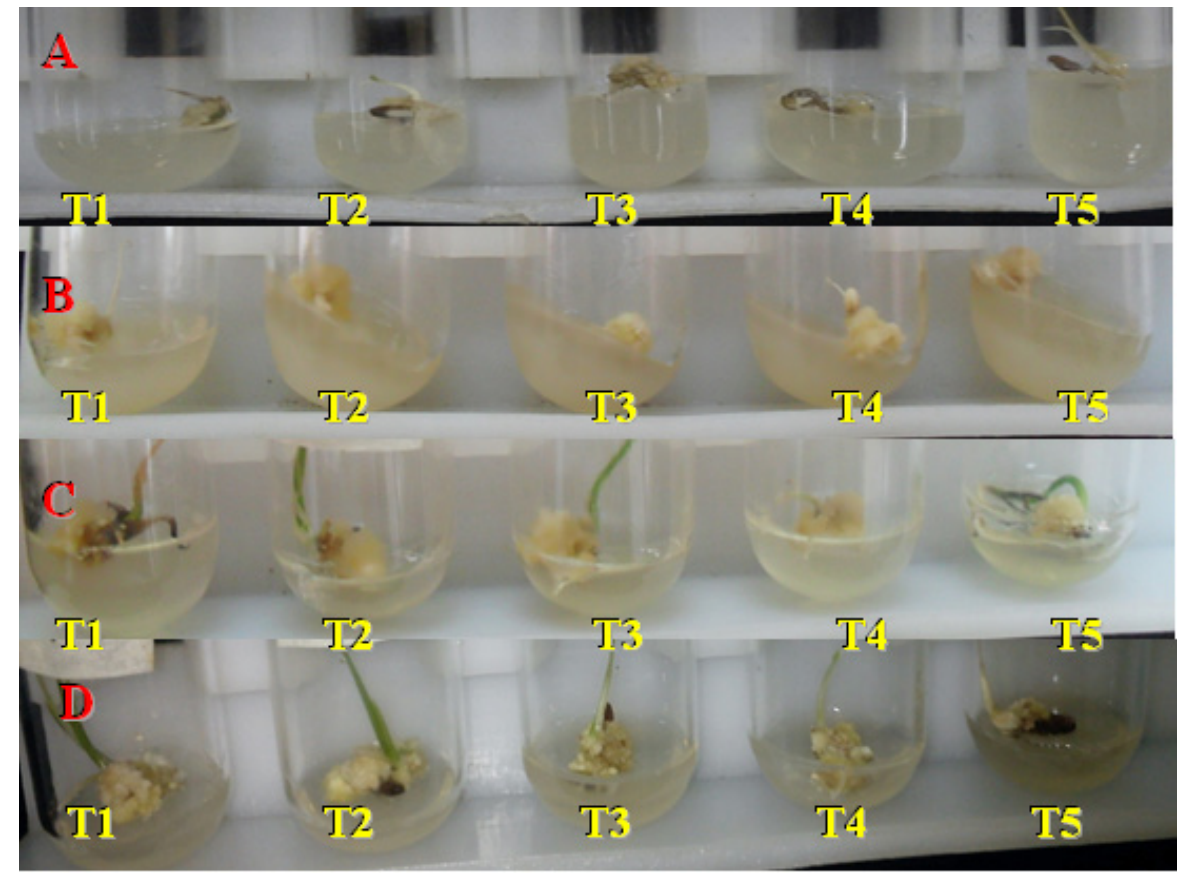

Plate 2. Callus diameter is high in traditional rice varieties Compare to improved rice varieties. A. At 362, B. Bg 358, C. Kaluheenati, D. Sulaai treated with T1. 1.0mg/1 2, 4-D +0.1mg/l BAP, T2. 1.5mg/l 2, 4-D+0.1mg/1 BAP, T3. 2.0mg/1 2, 4-D + 0.1mg/1 BAP, T4. 2.5mg/1 2, 4-D+0.1mg/1 BAP T5. $3.0 \mathrm{mg} / 1$ 2, 4-D + 0.1mg/1 BAP 


\section{Shoot induction}

\section{Number of days taken for shoot initiation}

Among ten tested varieties shoot induction was observed only $\mathrm{Bg} 358, \mathrm{Bg}$ 379 Sulaai and Suwadhal. Other all six tested rice varieties fail to produce shoots on any of the tested hormone concentration in MS basal medium. All regenerated varieties started to initiate shoots within three weeks. According to the results, $2.0 \mathrm{mg} / 1 \mathrm{BAP}+0.1 \mathrm{mg} / 1 \mathrm{IAA}$ is the best hormone combination for shoot induction within minimum number of days (7 days) compare to other varieties (Fig. 3).

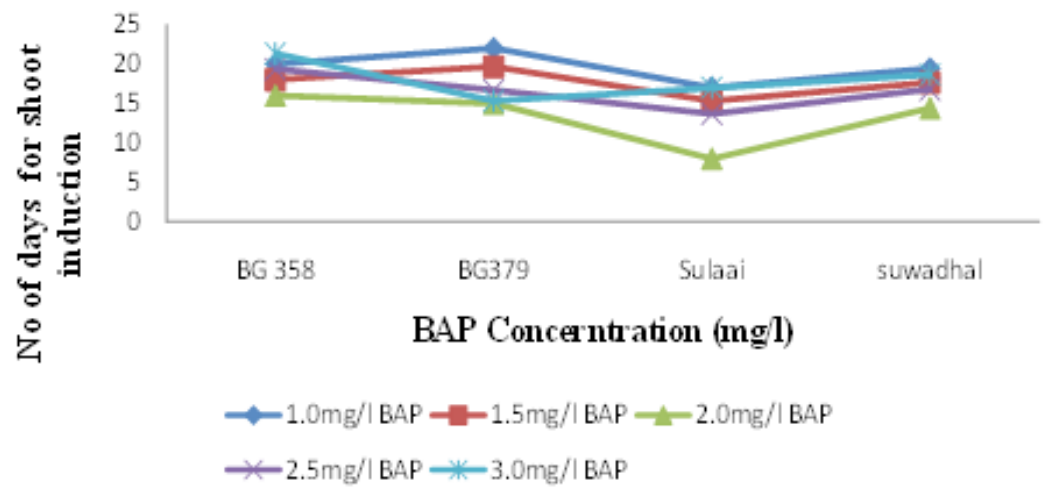

Figure 3: Number of days taken for shoots induction on different BAP concentrations. LSD value for comparison of two treatment means is 1.42

\section{Number of shoots per explants}

Highest percentage of shoots (59.69\%) was observed in Sulaai on MS basal medium supplement with $2.0 \mathrm{mg} / 1$ BAP with $0.1 \mathrm{mg} / 1$ IAA (Plate 3 ).

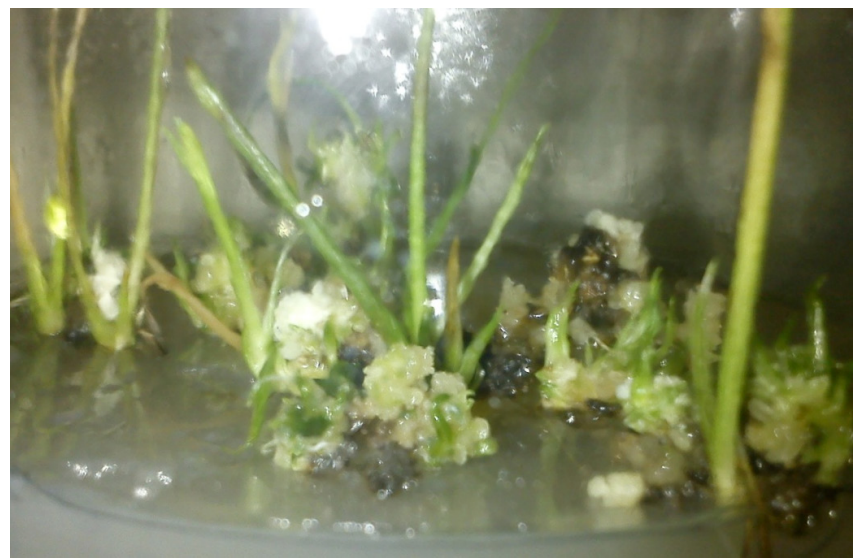

Plate 1. Highest percent of shoot induction in Sulaai on MS medium 2.0mg/1 0. IAA 
According to the results best medium for multiplication of rice shoot was MS basal medium with $2.0 \mathrm{mg} / 1 \mathrm{BAP}$ and $0.1 \mathrm{mg} / 1$ IAA (Figure 4, plate 4). But Dahanayaka et al (2011) was observed 2.5mg/1 BAP on MS basal medium best for plantlet regeneration of selected traditional rice varieties.

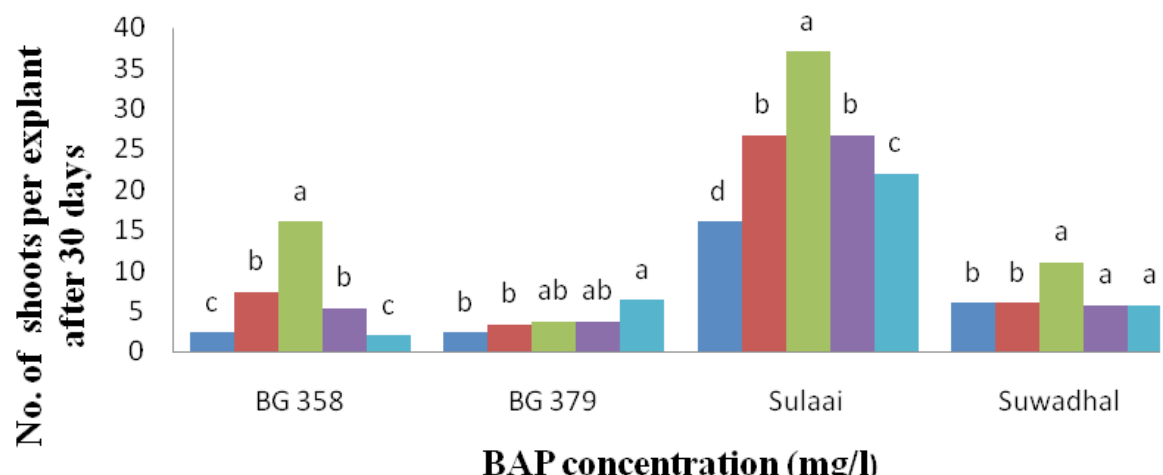

$\square \mathrm{BAP} 1.0 \mathrm{mg} / \mathrm{l} \square \mathrm{BAP} 1.5 \mathrm{mg} / \mathrm{l} \square \mathrm{BAP} 2.0 \mathrm{mg} / \mathrm{l} \square \mathrm{BAP} 2.5 \mathrm{mg} / \mathrm{l} \square \mathrm{BAP} 3.0 \mathrm{mg} / \mathrm{l}$

Figure 4 Effects of different BAP concentrations on number of shoots per explants. The figures with the same latter in each bar in same variety do not differ significantly according to DMRT 0.05. LSD value for comparison of two treatment means is 2.47
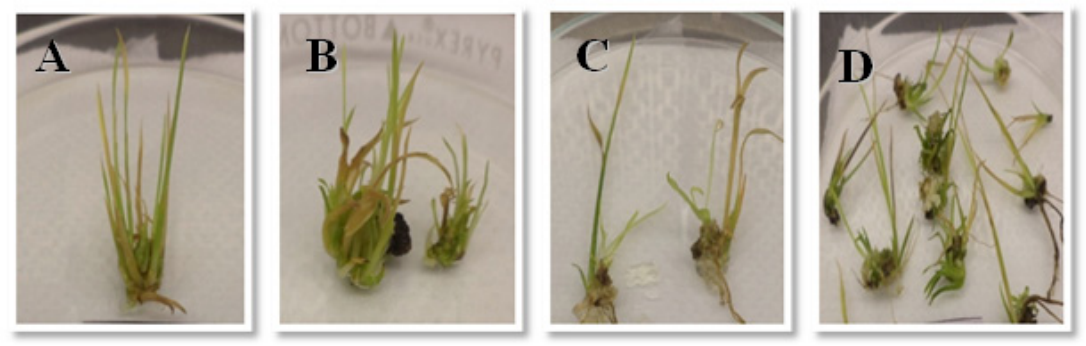

Plate 4. Highest number of multiple shoot was observed in MS basal medium supplement with 2.0mg/l BAP with $0.1 \mathrm{mg} / \mathrm{l} \mathrm{IAA}$. A.Bg379, B. Bg358, C. Suwadhal, D. Sulaai

\section{Root induction}

\section{Number of days taken for root induction}

All tested varieties were able to initiate roots within one week and rooting was observed in all tested IBA concentrations. But $2.0 \mathrm{mg} / 1 \mathrm{IBA}$ was taken minimum number of days for root induction compare to other tested IBA concentrations (Figure 5). 


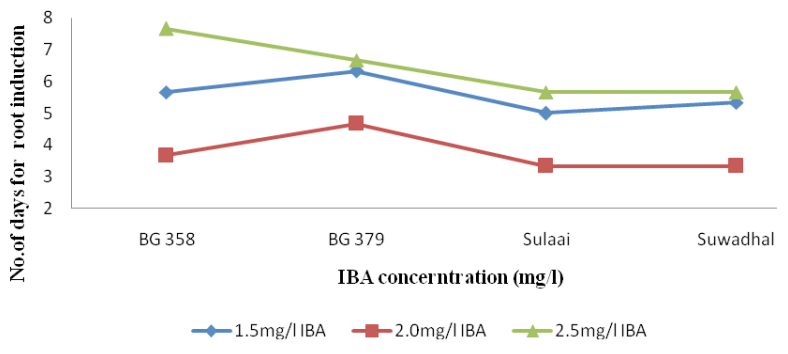

Figure 5: Effects of different IBA concentrations on days for Rooting. LSD value for comparison of two treatment means is 0.541

\section{Root length}

Significantly highest root length was observed on "Suwadhal" in MS basal medium supplemented with 2.0mg/1 IBA (Figure 6, Plate 5).

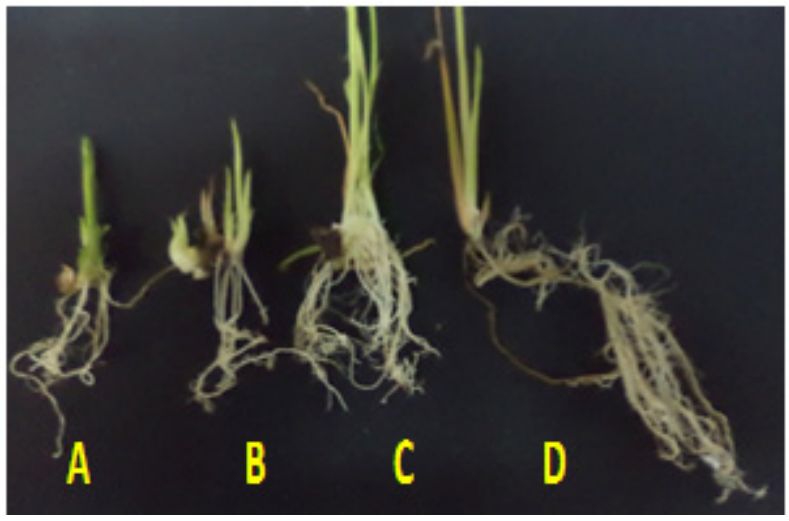

Plate 5: Root length of tested rice varieties (A. Bg358 B. Bg379 C. Sulaai D. Suwadhal) on MS basal medium supplement with $2.0 \mathrm{mg} / 1$

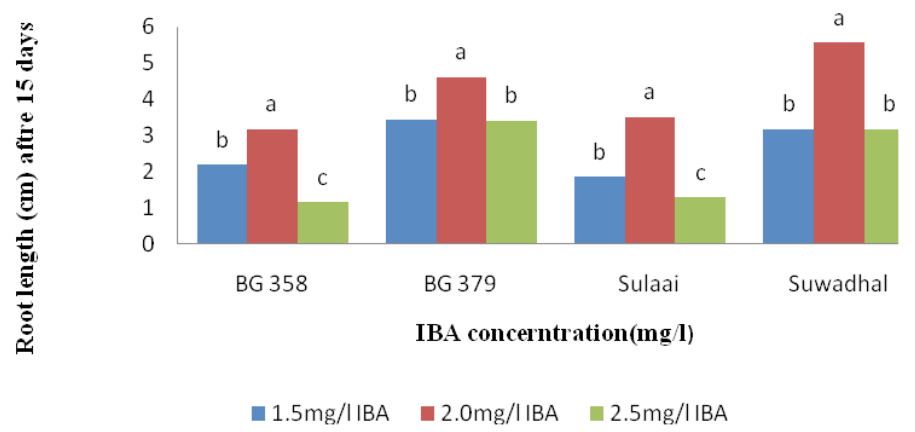

Figure 6: Effects of different IBA concentrations on Root length after 15days. LSD value for comparison of two treatment means is 0.235 


\section{References}

Agrawal, P.K., S.S. Gosal and G.S. Sidhu. 2006. Sequential reduction of 2 , 4-D improves whole plant regeneration from long-term maintained calli in some indica cultivars of rice. Oryza, 43:10-15.

Bregitzer, P., and M. Poulson.1995. Agronomical performance of barley lines derived from tissue culture. Crop sci., 35: 1144-1148.

Dahanayake N, Ranawake AL Tropical Agricultural Research \& Extension 15(2):2012 Calus induction and plantlet regeneration ability of selected Sri Lankan Traditionl rice cultivars (Oryza sativa L) in caryopses culture. Vol 15.

Hidayat Ullah, Iltaf Ullah, Sultan Akbar Jadoon and Hamid Rashid Sarhad Journal of. Agriculture. Vol. 23, No. 1, $2007: 81$ Tissue culture techniques for callus induction in rice Department of Plant Breeding and Genetics, NWFP Agricultural University, Peshawar - Pakistan

Pushpam, R. and S.R. Sree Rangasamy. 2000. In vitro response of rice genotypes to saltstress.Madras Agric. J., 87: 694-697.

Ram HH and HG Singh (1998) Crop breeding and genetics. Kalyani Publishers, NewDelhi, pp. 58-63.

Shanthi P, Jebaraj S, Geetha S and Aananthi N (2010) Electronic Journal of Plant Breeding, 1(4): 1200-1207 (July 2010) 2100 Effect of growth regulators on callusinduction in Rice embryo culture

(http://www.worldometers.info/world-population/). 